International Journal of Instruction

e-ISSN: 1308-1470 • www.e-iji.net
July $2019 \bullet$ Vol.12, No.3

p-ISSN: 1694-609X

pp. 119-132

Received: $14 / 10 / 2018$

Revision: 21/03/2019

Accepted: 27/03/2019

OnlineFirst:13/04/2019

\title{
Group Science Learning Model to Improve Collaborative Problem Solving Skills and Self-Confidence of Primary Schools Teacher Candidates
}

\author{
Ah. Zakki Fuad \\ Dr., UIN Sunan Ampel Surabaya, Indonesia,ah.zakki.fuad@uinsby.ac.id \\ Jauharoti Alfin \\ Dr., UIN Sunan Ampel Surabaya, Indonesia, alfin@uinsby.ac.id \\ Fauzan \\ Dr., UIN Syarif Hidayatullah, Indonesia,fauzan@ uinjkt.ac.id \\ Sri Astutik \\ Dr., University of Jember, Indonesia, tika.fkip@unej.ac.id \\ Binar Kurnia Prahani \\ Dr., State University of Surabaya, Indonesia, binarprahani@gmail.com
}

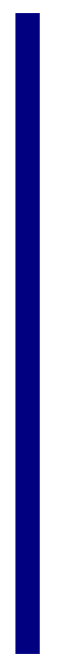

\begin{abstract}
Group Science Learning (GSL) is collaborative problem solving based learning by design to improve collaborative problem solving skills, science process skills, and self-confidence of primary schools teacher candidates. This research aims to analyze the effectiveness of GSL model to improve collaborative problem solving skills and self-confidence of primary schools teacher candidates on basic science learning in academic year 2018. This research used one group pre-test and post-test design on 119 primary schools' teacher candidates that were divided into four groups. The data collection methods were conducted by using collaborative problem solving skills test that was emphasized on participation indicator, perspective taking, social regulation, learning and knowledge building, and task regulation; questionnaire of self-confidence was emphasized on: ability indicator, motivation, and perseverance. The data analysis was done by using Paired sample $\mathrm{t}$-test and $\mathrm{n}$-gain. The results showed that there was a significant increase in collaborative problem solving skills and self-confidence at $\alpha=5 \%$, with post-test and n-gain score average in high category for all four groups. Thus, the GSL model is effective to enhance collaborative problem solving skills and self-confidence of primary schools' teacher candidates.
\end{abstract}

Keywords: collaborative problem solving skills, primary schools' teacher candidates, group science learning, self-confidence

Citation: Fuad, A. Z., Alfin, J., Fauzan, Astutik, S., \& Prahani, B. K. (2019). Group Science Learning Model to Improve Collaborative Problem Solving Skills and Self-Confidence of Primary Schools Teacher Candidates. International Journal of Instruction, 12(3), 119-132. https://doi.org/10.29333/iji.2019.1238a 


\section{INTRODUCTION}

To succeed in the global era, primary schools teacher candidates need skills that support them such as scientific creativity and innovation (Wicaksono, Wasis, \& Madlazim, 2017; Zulkarnaen, Supardi, \& Jatmiko, 2017), critical thinking, problem solving and collaborative skills (Alfin et al., 2019; Jatmiko et al., 2016; Pandiangan, Sanjaya, \& Jatmiko, 2017; Prayogi, Yuanita, \& Wasis, 2018; Siswanto, Susantini, \& Jatmiko, 2018; Yunus, Sanjaya, \& Jatmiko, 2013), literacy, communication, and metacognitive skills (Boleng, Lumowa, Palenewen, \& Corebima, 2017; Fauzi, 2013; Griffin \& Care, 2015; Huang, Hung, \& Cheng, 2012; Qatipi, 2011; Ramadani et al., 2015; Siregar et al., 2017; Syarifah et al., 2016).

The results of TIMSS and PISA studies showed that Indonesian students' problemsolving skills are in the lower levels (Martin et al., 2008; Martin et al., 2012; OECD, 2016). This is reinforced by preliminary study results at primary, junior and senior high schools, and in colleges for primary that are in primary teacher candidates education in Indonesia which show that generally collaborative problem-solving skills, science process skills, and confidence are in a low category (Alfin et al., 2019).

Some research results also indicate a lack of understanding of concepts, collaborative problem solving skills, science process skills, and self-confidence of teacher candidates (Alfin et al., 2019; Crawford, 2000; Zakar \& Baykara, 2014). The results of the research's Alfin et al. (2019) found some weaknesses of Problem Based Learning (PBL) and Collaborative Problem Solving (CPS) model that need to improved collaborative problem solving skills and primary schools teacher candidates' confidence. The need for innovation in the intervention is preferably on the model of learning to improve the skills of collaborative problem solving and primary schools teacher candidates' confidence.

Group Science Learning (GSL) is collaborative problem solving based learning by design to improve collaborative problem solving skills, science process skills, and selfconfidence of primary schools teacher candidates. The GSL model consists of five phases: (1) motivation and problem orientation, (2) collaborative problem solving activities, (3) presenting, (4) non-routine problem solving, and (5) evaluation. The sixth five have been designed to be interconnected with each other. Researchers developed a GSL model that refers to the flow of problem solving thinking by John Dewey (1929) that is supported by positive interdependent theory, cognitive-social constructivist theory, cognitive learning theory, and learning motivation theory. The GSL model improves the weaknesses of Problem Based Learning (PBL) model (Arends, 2012; Batdi, 2014; Celik et al., 2011; Sockalingam \& Schmidt, 2011) and Collaborative Problem-Solving (CPS) model (Mercier \& Higgins, 2014; Pollastri et al., 2013) to improve collaborative problem solving skills and primary schools teacher candidates' confidence.

The novelty of the GSL model if it is compared to the PBL model in improving collaborative problem-solving skills lies in phase 4: Non-Routine Problem-Solving (Alfin et al., 2019). This phase is specifically designed for primary school teacher 
candidates to undertake non-routine problem-solving that must be resolved collaboratively as a stage of enhancing their collaborative problem-solving skills as well as improving the confidence of primary school teacher candidates (Alfin et al., 2019). The novelties of the GSL model when compared to the CPS model are as follows. (1) In Phase 2: Collaborative Problem-solving Activities, learners are provided an based IoTs shared problem space that learners can optimize the use of multiple representations in collaborative problem-solving processes and the implementation of scientific process skills, as well as collaborative scientific (Alfin et al., 2019; Hesse et al., 2015; NRC, 2015; Mercier \& Higgins, 2014).

Prior research (Alfin et al., 2019) has proven the quality of the GSL model to improve problem solving skills, science process skills, and confidence of high school students, but it still needs further research to see the effectiveness of GSL model. While the criteria of intervention products include the GSL models can be said to be qualified if they meet the 3 criteria of valid, practical, and effective (Nieveen, McKenney, \& Akker, 2007; Plomp, 2013). In this research focus to analyze analysis of the GSL model effectiveness by analyzing the increase of collaborative problem solving skills and selfconfidence of service elementary teacher before and after following the process of GSL model. The scope of this research was the first-year students who took basic science course in academic year 2018.

\section{Problem of Research}

The main problem of this research to analyze the effectiveness of the GSL model on improving collaborative problem solving skills and self-confidence of pre-service elementary teacher on basic science learning. The focus problem in this research includes: (1) How much is the level of collaborative problem solving skills and selfconfidence of pre-service elementary teacher enhancement in post-test? (2) Whether there is a significant (statistically) increase collaborative problem solving skills and selfconfidence of pre-service elementary teacher before and after the GSL model is applied? (3) How much is the level of collaborative problem solving skills and self-confidence of pre-service elementary teacher enhancement before and after the application of GSL model? The researchers hope to qualify the intervention product that is the effectiveness of GSL model to improve the collaborative problem solving skills and self-confidence of pre-service elementary teacher on basic science learning.

\section{METHOD}

\section{Sample of Research}

This research was conducted at State Islamic University of Sunan Ampel (Surabaya, Indonesia) in February - April 2018. In this research, populations were taken from 169 pre-service elementary teachers at State Islamic University of Sunan Ampel, Surabaya, Indonesia. The sample in this research were 119 pre-service elementary teachers at State Islamic University of Sunan Ampel, Surabaya, Indonesia; which were arranged in four groups: group-1 (31 pre-service elementary teacher), group-2 (30 pre-service elementary teacher), group-3 (27 pre-service elementary teacher), and group-4 (31 pre-service 
elementary teachers). Each group took basic science course in academic year 2018 at State Islamic University of Sunan Ampel, Surabaya, Indonesia.

\section{Instrument}

The collaborative problem solving skills test consists of 5 items referring to the scientific creativity indicators were adapted from Griffin \& Care (2015), they include: participation, perspective taking, social regulation, learning and knowledge building, and task regulation. Questionnaire of primary schools teacher candidates' selfconfidence was adapted from Gok (2012) that are emphasized on ability, motivation, and perseverance. The assessment instruments, namely the collaborative problem solving skills test and self-confidence questionnaire were also declared valid and practical.

\section{Procedures}

This research has used one group of pre-test and post-test design, namely $\mathrm{O} 1 \mathrm{X} \mathrm{O} 2$ (Fraenkel, Wallen, \& Hyun, 2012). The learning process has begun by giving a pre-test (O1). Each primary schools teacher candidates has been asked to work on a pre-test of collaborative problem solving skills, then after that, students have been asked to fill out the self-confidence questionnaire of the primary schools teacher candidates. The collaborative problem solving skills test consists of 5 items which refer to the collaborative problem solving skills indicators adapted from Griffin \& Care (2015), which include: participation, perspective taking, social regulation, knowledge learning and development, and task regulation. Questionnaire for self-confidence of primary schools teacher candidates was adapted from Gok (2012) which emphasized on ability, motivation, and perseverance. After the pre-test, lecturers have implemented GSL teaching models and materials in each group $(\mathrm{X})$. The implementation of the GSL model has been conducted for one semester. Learning materials have been specifically designed to be integrated with indicators of collaborative problem solving skills which consist of: participation, perspective taking, social regulation, knowledge learning and development, and task regulation; and indicators of confidence that consist of: ability, motivation, and perseverance. The teaching process ends with a post-test $(\mathrm{O} 2)$. Each primary schools teacher candidates has been asked to post-test collaborative problem solving skills, then after that, primary schools teacher candidates have been asked to fill out the self-confidence questionnaire.

\section{Data Analysis}

The effectiveness of the GSL model was analyzed based on the assessments that was determined before and after using the GSL model. The results of pre-test, post-test, and n-gain of pre-service elementary teacher's collaborative problem solving skills and selfconfidence were further analyzed by using inferential statistics with the help of SPSS 16 software. The choice of statistical testing methods relies on fulfilling the assumptions of normality and homogeneity variants for pre-test, post-test, and n-gain. Statistical test use Kolmogorov test (test of normality), Levene test (homogeneity variants), and Paired ttest (analysis of statistical improvement). 


\section{FINDINGS}

The learning outcomes of four groups of collaborative problem solving skills are presented in Figure 1 and Table 1. Figure 1 shows that the average post-test scores of collaborative problem solving skills in the basic science course for all groups is greater than the pre-test score. The average pre-test, post-test, and n-gain scores that are associated with collaborative problem solving skills indicators for all groups are presented in detail in Table 1.

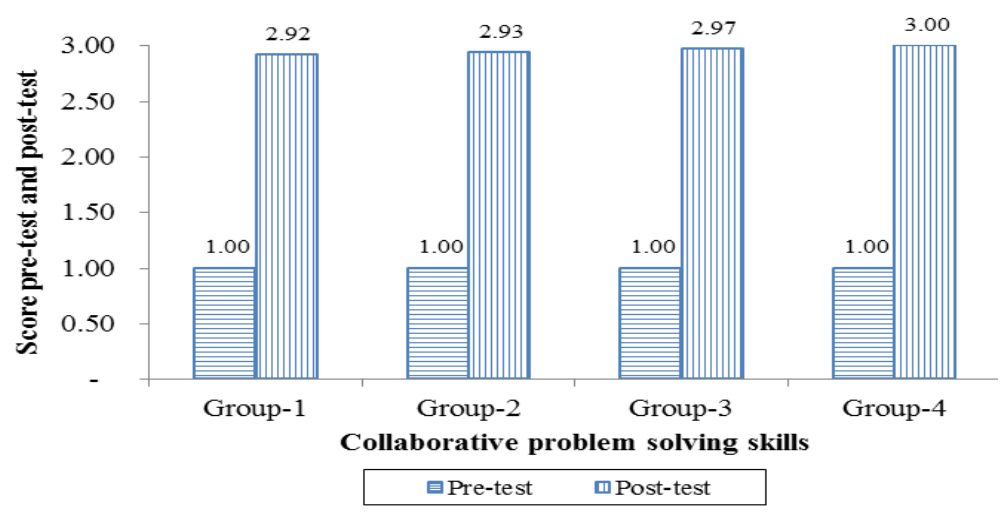

Figure 1

The average pre-test and post-test scores of collaborative problem solving skills in all groups

Table 1

The average pre-test, post-test, and n-gain scores of collaborative problem solving skills for all groups

\begin{tabular}{|c|c|c|c|c|c|c|c|c|c|c|c|c|}
\hline \multirow[t]{2}{*}{ Group } & \multirow[t]{2}{*}{$\mathrm{N}$} & \multirow[t]{2}{*}{ Scores } & \multicolumn{10}{|c|}{ Collaborative Problem Solving Skills Indicator } \\
\hline & & & $\mathrm{P}$ & & PT & & SR & & LKB & & TR & \\
\hline \multirow[t]{3}{*}{ G1 } & 31 & $\mathrm{O} 1$ & 1.00 & $\mathrm{~L}$ & 1.00 & $\mathrm{~L}$ & 1.00 & $\mathrm{~L}$ & 1.00 & $\mathrm{~L}$ & 1.00 & $\mathrm{~L}$ \\
\hline & & $\mathrm{O} 2$ & 3.00 & $\mathrm{H}$ & 3.00 & $\mathrm{H}$ & 2.84 & $\mathrm{H}$ & 2.84 & $\mathrm{H}$ & 2.90 & $\mathrm{H}$ \\
\hline & & $\langle\mathrm{g}\rangle$ & 1.00 & $\mathrm{H}$ & 1.00 & $\mathrm{H}$ & .92 & $\mathrm{H}$ & 0.92 & $\mathrm{H}$ & 0.95 & $\mathrm{H}$ \\
\hline \multirow[t]{3}{*}{ G2 } & 30 & $\mathrm{O} 1$ & 1.00 & $\mathrm{~L}$ & 1.00 & $\mathrm{~L}$ & 1.00 & $\mathrm{~L}$ & 1.00 & $\mathrm{~L}$ & 1.00 & $\mathrm{~L}$ \\
\hline & & $\mathrm{O} 2$ & 3.00 & $\mathrm{H}$ & 3.00 & $\mathrm{H}$ & 2.90 & $\mathrm{H}$ & 2.97 & $\mathrm{H}$ & 2.80 & $\mathrm{H}$ \\
\hline & & $\langle\mathrm{g}\rangle$ & 1.00 & $\mathrm{H}$ & 1.00 & $\mathrm{H}$ & .95 & $\mathrm{H}$ & 0.98 & $\mathrm{H}$ & 0.90 & $\mathrm{H}$ \\
\hline \multirow[t]{3}{*}{ G3 } & 27 & $\mathrm{O} 1$ & 1.00 & $\mathrm{~L}$ & 1.00 & $\mathrm{~L}$ & 1.00 & L & 1.00 & $\mathrm{~L}$ & 1.00 & $\mathrm{~L}$ \\
\hline & & $\mathrm{O} 2$ & 3.00 & $\mathrm{H}$ & 3.00 & $\mathrm{H}$ & 2.89 & $\mathrm{H}$ & 3.00 & $\mathrm{H}$ & 2.96 & $\mathrm{H}$ \\
\hline & & $\langle\mathrm{g}\rangle$ & 1.00 & $\mathrm{H}$ & 1.00 & $\mathrm{H}$ & .94 & $\mathrm{H}$ & 1.00 & $\mathrm{H}$ & 0.98 & $\mathrm{H}$ \\
\hline \multirow[t]{3}{*}{ G4 } & 31 & O1 & 1.00 & $\bar{L}$ & 1.00 & $\bar{L}$ & 1.00 & $\mathrm{~L}$ & 1.00 & $\bar{L}$ & 1.00 & $\mathrm{~L}$ \\
\hline & & $\mathrm{O} 2$ & 3.00 & $\mathrm{H}$ & 3.00 & $\mathrm{H}$ & 3.00 & $\mathrm{H}$ & 3.00 & $\mathrm{H}$ & 3.00 & $\mathrm{H}$ \\
\hline & & $\langle\mathrm{g}\rangle$ & 1.00 & $\mathrm{H}$ & 1.00 & $\mathrm{H}$ & 1.00 & $\mathrm{H}$ & 1.00 & $\mathrm{H}$ & 1.00 & $\mathrm{H}$ \\
\hline
\end{tabular}

Note: N (Sample); G1 (Group-1); G2 (Group-2); G3 (Group-3); G4 (Group-4); L (Low); M (Moderate); H (High); O1 (pre-test); O2 (post-test); 〈g > (n-gain) P (Participation); PT (Perspective Taking); SR (Social Regulation); LKB (Learning and Knowledge Building); TR (Task Regulation)

The average pre-test and post-test scores of self-confidence for all groups are presented in Figures 2 and Table 2. 


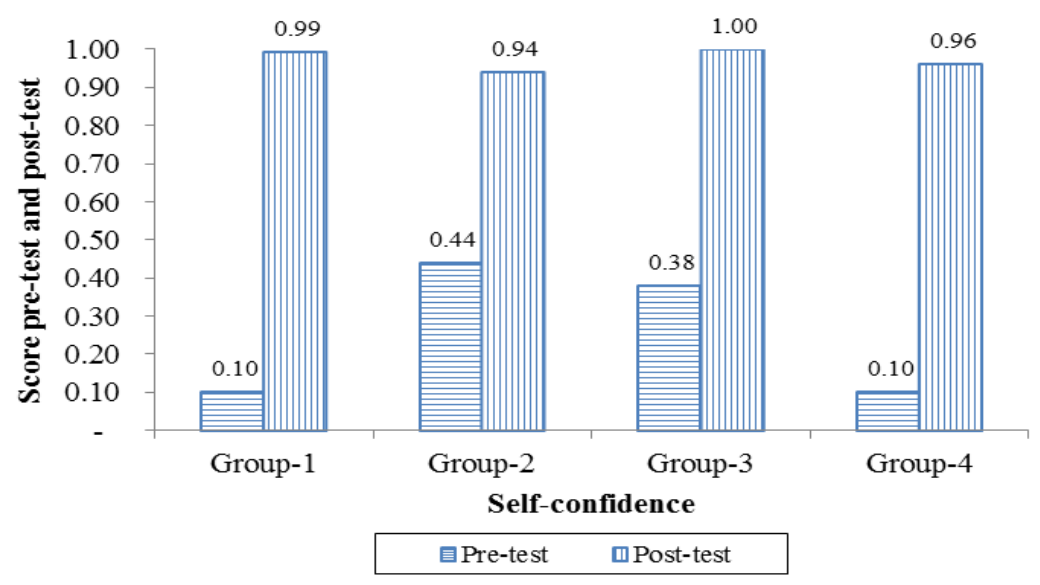

Figure 2

The average pre-test and post-test scores of self-confidences in all groups

Figure 2 shows that the average post-test score of self-confidence for all groups is also greater than the pre-test score. The average pre-test, post-test, and n-gain scores that are associated with the self-confidence indicators for all groups are presented in detail in Table 2.

Table 2

The average score of pre-test, post-test and n-gain of self-confidence in all groups

\begin{tabular}{cllllllll}
\hline \multirow{2}{*}{ Group } & \multirow{2}{*}{ Sample } & \multirow{2}{*}{ Scores } & \multicolumn{2}{l}{ Self-confidence Indicator } \\
\cline { 4 - 9 } & & & Ability & \multicolumn{3}{l}{ Motivation } & \multicolumn{2}{l}{ Perseverance } \\
\hline Group-1 & \multirow{2}{*}{31} & Pre-test & 0.10 & Low & 0.10 & Low & 0.10 & Low \\
& & Post-test & 0.80 & High & 0.67 & High & 0.76 & High \\
& & N-gain & 0.80 & High & 0.67 & High & 0.76 & High \\
\hline Group-2 & \multirow{2}{*}{30} & Pre-test & 0.34 & Low & 0.31 & Low & 0.34 & Low \\
& & Post-test & 0.75 & High & 0.62 & High & 0.73 & High \\
& & N-gain & 0.63 & High & 0.45 & High & 0.60 & High \\
\hline Group-3 & 27 & Pre-test & 0.30 & Low & 0.37 & Low & 0.39 & Low \\
& & Post-test & 0.79 & High & 0.69 & High & 0.77 & High \\
& & N-gain & 0.70 & High & 0.50 & High & 0.62 & High \\
\hline Group-4 & \multirow{2}{*}{31} & Pre-test & 0.10 & Low & 0.10 & Low & 0.10 & Low \\
& & Post-test & 0.75 & High & 0.67 & High & 0.74 & High \\
& & N-gain & 0.75 & High & 0.67 & High & 0.74 & High \\
\hline
\end{tabular}




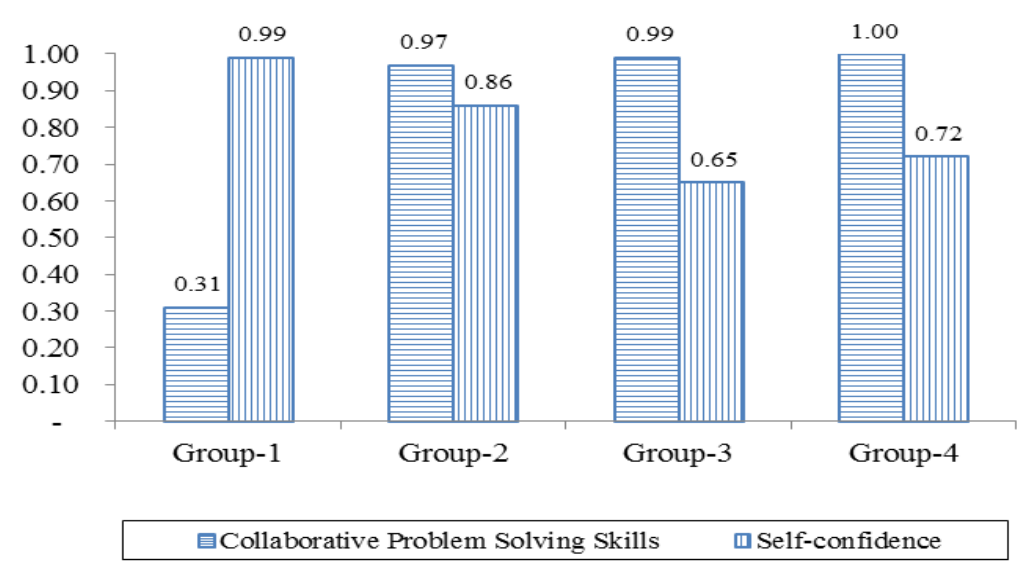

Figure 3

The average n-gain of collaborative problem solving skills and self-confidence in all groups

Figure 3 shows the average n-gain value of collaborative problem solving skills for group-1, group-2, group-3, and group-4 are respectively $0.31 ; 0.97 ; 0.99$; and 1.00 . Therefore, the impact of learning with the GSL model on improving collaborative problem solving skills and self-confidence for the whole group used paired sample t-test.

Table 3

Paired sample t-test result of collaborative problem solving skills for all groups

\begin{tabular}{|c|c|c|c|c|c|c|}
\hline \multirow{2}{*}{ Group } & \multirow{2}{*}{$\mathrm{N}$} & \multicolumn{5}{|c|}{ Paired t-test $(\alpha=5 \%)$} \\
\hline & & Mean & Std. error mean & $\mathrm{t}$ & Df & $\mathrm{p}$ \\
\hline Group-1 & 31 & -1.91 & 0.03 & -53.74 & 30 & $<.001$ \\
\hline Group-2 & 30 & -1.93 & 0.02 & -65.99 & 29 & $<.001$ \\
\hline Group-3 & 27 & -1.97 & 0.02 & -95.90 & 26 & $<.001$ \\
\hline Group-4 & 31 & -1.99 & 0.03 & -309.00 & 30 & $<.001$ \\
\hline
\end{tabular}

Table 3 shows that the average collaborative problem solving skills for group 1, 2, 3, and 4 are $-1.91,-1.93,-1.97,-1.99$ and have degrees of freedom $(\mathrm{df})=30,29,26,30, \mathrm{t}$ score gives $t$ value $=-53.74,-65.99,-95.90,-309.00$ for all groups. Negative values indicate pre-test mean score < post-test mean score. The score is significant, because $\mathrm{p}<$ .05 .

Table 4

Paired t-test results of self-confidence for all groups

\begin{tabular}{lllllll}
\hline \multirow{2}{*}{ Group } & \multirow{2}{*}{$\mathrm{N}$} & \multicolumn{2}{l}{ Paired t-test $(\alpha=5 \%)$} & & \\
\cline { 3 - 7 } & & Mean & Std. error mean & $\mathrm{t}$ & $\mathrm{Df}$ & $\mathrm{P}$ \\
\hline Group-1 & 31 & -0.74 & 0.01 & -39.56 & 30 & $<.001$ \\
Group-2 & 30 & -0.41 & 0.02 & -15.07 & 29 & $<.001$ \\
Group-3 & 27 & -0.45 & 0.02 & -20.83 & 26 & $<.001$ \\
Group-4 & 31 & -0.71 & 0.01 & -41.64 & 30 & $<.001$ \\
\hline
\end{tabular}


Table 4 shows the average of self-confidence for groups $1,2,3$, and 4 are $-0.74,-0.41$, $0.45,-0.71$ and the $t$ score gives $t$ value $=-39.56,-15.07,-20.83,-41.64$ for degrees of freedom $(\mathrm{df})=30,29,26,30$ for all groups. In addition, the score is significant, because $\mathrm{p}<.05$.

\section{DISCUSSION}

\section{Collaborative Problem Solving Skills}

Before the GSL model was applied, students less master the collaborative problem solving skills, the average score of the students is under the standard score. All this time, students are not used to participate, do perspective taking, social regulation, learning and knowledge building, and task regulation. These findings indicate primary schools teacher candidates have difficulties in the implementation of collaborative problem solving skills during the process of solving the problems they face. In line with the findings of Alfin's et al (2019) that problem solving skills of primary schools teacher candidates not being the main assessment and have not been supported by adequate learning tools.

Conversely, after the GSL model was applied to the basic science course, the mastery of collaborative problem solving skills of primary schools teacher candidates develop above average and becomes high. The improvement of the collaborative problem solving skills was because they were guided by the lecturers in Phase 2: Collaborative Problem Solving Activities. The activities of primary schools teacher candidates in the routine problem solving activities (academic) in worksheet 1 as an effort to train collaborative problem solving skills and self-confidence (motivation, perseverance, and ability) in the learning process, namely: (1) primary schools teacher candidates make problem formulation (2) primary schools teacher candidates share insights in making hypotheses, (3) primary schools teacher candidates learn and build knowledge during the activities of identifying variables and make operational definitions of experimental variables; (4) primary schools teacher candidates are actively involved in participation to collect information (experiment), make a graph, analyze, and make conclusions, and (5) do self-reflection as a form of social regulation. The results of this research are consistent with Burns, Pierson, \& Reddy (2014), DeWitt, Siraj, \& Alias (2014), Laal \& Ghodsi (2012) that problem-solving skills with collaboration can be trained on learners in which learners' groups build knowledge through working together in the social environment to learn and solve a problem or produce a product.

Table 2 and Figure 3 show the increase of collaborative problem solving skills score in all groups were significant at the 5\%, significance level for group-1, group-2, group-3, and group-4. The improvement of collaborative problem solving skills was due to the GSL model provides a learning environment in which students can be active in collaborative problem-solving activities, thus it directly affects their collaborative problem-solving skills. In collaborative problem solving, students must understand the information of the problem they faces through individual cognitive processes before entering the collaborative problem-solving process. According to the cognitive constructivist theory by Piaget $(1954,1963)$, every student of any age is actively 
involved in the process of acquiring information and constructing their own knowledge (Arends, 2012).

Table 1 shows an increase in all indicators of collaborative problem-solving skills include the regulation of tasks, shared views, learning and knowledge building, participation, and social regulation. It cannot be separated from the role of valid learning tools to improve collaborative problem solving skills. In addition, improved indicators of collaborative problem-solving skills have been trained by design in every GSL model phase. For example in Phase 3: Presenting, (1) Lecturer guides primary schools teacher candidates to present and communicate the results of collaborative problem-solving activities to other groups. (2) Lecturer guides primary schools teacher candidates for the internalization of concepts, collaborative problem solving skills and fosters their confidence through presentation activities. The improvement results of all students' collaborative problem-solving skills indicators are in line with previous research findings that students should have the ability to identify shared knowledge identities, identify other students' perspectives on collaboration, and build a shared vision of issues and activities (OECD, 2014). The finding of enhanced collaborative problem-solving skills fits the with Vygotsky's social constructivist theory, this theory has four major implications: (1) social learning; students learn through interaction with more capable adults and peers; (2) Zone of Proximal Development (ZPD); students learn the best concepts when they are in their nearest development zone; (3) cognitive apprenticeship; the process in which a student achieves expertise step by step in his interaction with an expert, whether an adult or a peer whose knowledge is higher; (4) scaffolding; students should be given complex, difficult, and realistic tasks and then be given sufficient help to solve these tasks (Slavin, 2011). The above findings prove that the GSL model is effective to improve the collaborative problem solving skills of primary schools teacher candidates.

\section{Self-Confidence}

Before the GSL model was applied, students are not used to have ability, motivation, and perseverance. These findings show primary schools teacher candidates have difficulty in implementing self-confidence during the process of solving the problems they face. The low self-esteem of students is in accordance with the results of TIMSS research in 2011 that students' confidence criteria in Science-Physics in Indonesia is at the bottom of the list (Martin, Mullis, Foy, \& Stanco, 2012).

Conversely, after the GSL model was applied to the basic science course, the mastery of self-confidence of primary schools teacher candidates rises above average and becomes high. This increase in self-confidence was because the primary schools teacher candidates were guided by lecturers in Phase 2: Collaborative Problem Solving and Phase 3: Presentation Activities. In Phase 2: Collaborative problem solving Activities; (1) Lecturer divides the primary schools teacher candidates in the heterogeneous (expert and novice) groups (3-4 primary schools teacher candidates) and divides the worksheet. (2) Lecturer guides primary schools teacher candidates in routine (academic) problem solving activities in worksheet 1 as an effort to train collaborative problem-solving skills and instill confidence in the learning process. This is reinforced in Phase 3: Presentation 
that includes: (1) Lecturer guides primary schools teacher candidates to present / communicate the results of collaborative problem-solving activities to classical / to other groups; (2) Lecturer guides primary schools teacher candidates for the internalization of concepts, collaborative problem solving skills and fosters their confidence through presentation activities. The results of this research are aligned by Keller (2010) that to improve students' self-confidence, teachers should be able to apply the learning needs, success opportunities, and personal controls.

Table 2 shows an increase in all self-confidence indicators include the ability, motivation, and perseverance. It cannot be separated from the role of learning tools that are valid to improve self-confidence. In addition, improvements in self-confidence indicators have been trained by design in each GSL model phase. For example, in Phase 4: Non-Routine Problem Solving, Primary schools teacher candidates do follow-up work in the form of worksheet 2 non-routine problem solving (authentic) that must be solved collaboratively as a stage of enhancing their collaborative problem solving skills as well as improving their self-confidence (motivation, and confident in the ability). Phase 4: Non-Routine Problem Solving is specifically designed to enable students to work on non-routine problem solving (so-called authentic problems in everyday life) that must be resolved collaboratively as a stage of enhancing their collaborative problem-solving skills and improving their self-confidence. Table 4 and Figure 3 show the increase of self-confidence score in all groups was significant at the 5\%, significance level for group-1, group-2, group-3, and group-4 are respectively $<0.001$. The increased confidence in this research cannot be separated from the role of learning model that are valid to improve self-confidence. This is supported by the results of the research (Alfin et al., Husamah, Fatmawati, \& Setyawan, 2018) that the model that is feasible to meet the validity, practicality, and effectiveness will be able to improve and achieve the learning objectives. The fundamental implication of this research is a science innovative learning model to improve the collaborative problem solving skills and self-confidence of primary schools teacher candidates. The result of all self-confidence indicators of primary schools teacher candidates is in line with the ARCS theory, Confidence, the learner to believe that there is an acceptable probability to succeed for them to be motivated, this expectancy for success is synonymous with (Keller, 2010). Teachers must be able to optimize the motivation and confidence in order to make students become successful in learning. The theory is relevant to Gok's findings (2014) that the performance of individual problem solving has a positive relationship with students' self-confidence and peer instruction can increase students' confidence in problem solving (Brooks \& Koretsky, 2011; Vickrey, Rosploch, Rahmanian, Pilarz, \& Stains, 2015). The above findings prove that the GSL model is effective to improve the collaborative problem solving skills and self-confidence of primary schools teacher candidates.

\section{CONCLUSIONS}

The results of this research indicate that the GSL model is effective to improve the collaborative problem solving skills and self-confidence of primary schools teacher candidates based on: the average post-test score of collaborative problem solving skills 
and self-confidence were at high category; (2) there was significant increase (statistically) at the level of significance, $\alpha=5 \%$; and (3) the level of increase that was determined by the normalized gain value, (n-gain) is high. Development of collaborative problem solving skills and self-confidence through the GSL model is expected to facilitate primary schools teacher candidates to achieve their success in the future. The implications of this research can be an alternative to overcome the problems of $21 \mathrm{st}$ century education in the related to the problem of the low level collaborative problem solving skills and self-confidence on the basic science course. Further research can be done to implement GSL model at the elementary, middle and upper level of education.

\section{REFERENCES}

Alfin, J., Fuad, A. Z., Nur, M., Yuanita, L., \& Prahani, B. K. (2019). Development of group science learning (GSL) model to improve the skills of collaborative problem solving, science process, and self-confidence of primary schools teacher candidates. International Journal of Instruction, 12(1), 1-18.

Arends, R. I. (2012). Learning to teach. New York: Mc.Graw-Hill.

Batdi, V. (2014). The effects of problem based learning approach on students' attitude levels: A meta-analysis. Educational Research and Review, 9(9), 272-276.

Boleng, D. T., Lumowa, S. V., Palenewen, E., \& Corebima, A. D. (2017). The effect of learning models on biology critical thinking skills of multiethnic students at senior high schools in Indonesia. Problems of Education in the 21st Century, 75(2), 136-143.

Brooks, B. B. J., \& Koretsky, M. D. M. (2011). The influence of group discussion on students responses and confidence during peer instruction. Journal of Chemical Education, 88(11), 1477-1484.

Burns, M., Pierson, E., \& Reddy, S. (2014). Working together: How teachers teach and students learn in collaborative learning environments. International Journal of Instruction, 7(1), 17-32.

Celik, P., Onder, F., \& Silay, I. (2011). The effects of problem-based learning on the students' success in physics course. Proceeding Social and Behaviour Science, 28, 656600 .

Crawford, B. A. (2000). Embracing the essence of inquiry: New roles for science teachers. Journal Research Science Teaching, 37(9), 916-937.

DeWitt, D., Siraj, S., \& Alias, N. (2014). Collaborative learning: A module for learning secondary school science. Educational Technology \& Society, 17(1), 89-101.

Fauzi, A. (2013). Pengaruh kemampuan akademik terhadap keterampilan metakognitif, hasil belajar biologi, dan retensi siswa SMA Kelas $X$ dengan penerapan strategi pembelajaran cooperative script di Malang. Malang: Universitas Negeri Malang.

Fraenkel, J., Wallen, N., \& Hyun, H. (2012). How to design and evaluate research in education. New York: McGraw-Hill. 
Gok, T. (2012). Developing of problem solving confidence questionnaire: Study of validation and reliability. Latin American Journal Physics Education, 6 (1), 21-26.

Gok, T. (2014). Students' achievement, skill and confidence in using stepwise problemsolving strategies. Eurasia Journal Mathematic Scientific \& Technology Education, 10(6), 617-624.

Griffin, P., \& Care, E. (2015). Assessment and teaching of 21st century skills: Methods and approach. New York: Springer.

Hake, R. R. (1998). Interactive-engagement versus traditional methods: A six-thousandstudent survey of mechanics test data for introductory physics courses. American Journal of Physics, 66(1), 64-74.

Huang, K. H., Hung, K. C., \& Cheng, C. C. (2012). Enhancing interactivity in geography class: fostering critical thinking skills through technology. Problems of Education in the 21st Century, 50(1), 32-45.

Husamah, Fatmawati, D., \& Setyawan, D. (2018). OIDDE learning model: Improving higher order thinking skills of biology teacher candidates. International Journal of Instruction, 11(2), 249-264.

Jatmiko, B., Widodo, W., Martini, Budiyanto, M., Wicaksono, I., \& Pandiangan, P. (2016). Effectiveness of the INQF-based learning on a general physics for improving student's learning outcomes. Journal of Baltic Science Education, 15(4), 441-451.

Laal, M., \& Ghodsi, M. S. (2012). Benefits of collaborative learning. Procedia Social and Behavioral Science, 31, 486-490.

Martin, M. O., Mullis, I. V., Foy, P., \& Stanco, G. M. (2012). TIMSS 2011: International Science Report. Boston: TIMSS and PIRLS International Study.

Mercier, E., \& Higgins, S. (2014). Creating joint representations of collaborative problem solving with multi-touch technology. Journal Computer Assisted Learning, 30(6), 497-510.

Nieveen, N., McKenney, S., \& Van Akker. (2007). Educational design research. New York: Routledge.

OECD. (2014). PISA 2012 results: What students know and can do-student performance in mathematics, reading and science. Washington: OECD Publishing.

OECD. (2016). PISA 2015 Result in Focus. Washington: OECD Publishing.

Pandiangan, P., Sanjaya, M., Gusti, I., \& Jatmiko, B. (2017). The validity and effectiveness of physics independent learning model to improve physics problem solving and self-directed learning skills of students in open and distance education systems. Journal of Baltic Science Education, 16(5), 651-665. 
Plomp, T. (2013). Preparing education for the information society: The need for new knowledge and skills. International Journal of Social Media and Interactive Learning Environments, 1(1), 3-18.

Pollastri, R. A., Epstein, D. L., Heath, H. G., \& Ablon, S. J. (2013). The collaborative problem solving approach: Outcomes across Settings. Perspectives, 21(4), 188-199.

Prayogi, S., Yuanita, L., \& Wasis. (2018). Critical inquiry based learning: A model of learning to promote critical thinking among prospective teachers of physics. Journal of Turkish Science Education, 15(1), 43-56.

Qatipi, S. (2011). Questioning and its true values in the process of learning and teaching to promote critical thinking. Problems of Education in the 21st Century, 38, 71-81.

Ramadani, S. D., Fauzi, A., Sukmawati, I., \& Corebima, A. D. (2015). Perbandingan potensi strategi pembelajaran cooperative script dan reciprocal teaching dalam memberdayakan keterampilan metakognitif, hasil belajar Biologi, dan retensi siswa SMA. In Proceedings of the 2nd Seminar \& Workshop Nasional Biologi, IPA, dan Pembelajarannya FMIPA UM. 655-661. Malang: Biologi FMIPA UM.

Siregar, I. Y., Susilo, H., \& Suwono, H. (2017). Pengaruh think-pair-share-write berbasis hybrid learning terhadap keterampilan metakognitif, berpikir kreatif dan hasil belajar kognitif siswa SMA Negeri 3 Malang. JPBI (Jurnal Pendidikan Biologi Indonesia), 3(2), 183-193.

Siswanto, J., Susantini, E., \& Jatmiko, B. (2018) Multi-representation based on scientific investigation for enhancing students' representation skills. Journal Physics: Conference Series, 983, 012034.

Siswanto, J., Susantini, E., \& Jatmiko, B. (2018). Practicality and effectiveness of the IBMR teaching model to improve physics problem solving skills. Journal of Baltic Science Education, 17(3), 381-394.

Slavin, E. R. (2011). Educational psychology: Theory and practice. Boston: Pearson.

Sockalingam, N., \& Schmidt, H. G. (2011). Characteristics of problems for problembased learning: The students' perspective. Interdisciplinary Journal of Problem-Based Learning, 5(1), 6-33.

Susantini, E., Isnawati, \& Lisdiana, L. (2016). Effectiveness of genetics student worksheet to improve creative thinking skills of teacher candidate students. Journal of Science Education, 2(17), 74-79.

Syarifah, H., Indriwati, S. E., \& Corebima, A. D. (2016). Perbedaan keterampilan metakognitif dan motivasi siswa putra dan putri kelas X SMAN di Kota Malang melalui strategi pembelajaran Reading Questioning and Answering (RQA) dipadu Think Pair Share (TPS), JPBI (Jurnal Pendidikan Biologi Indonesia), 2(1), 10-18. 
Vickrey, T., Rosploch, K., Rahmanian, R., Pilarz, M., \& Stains, M. (2015). Researchbased implementation of peer instruction: A literature review. CBE-Life Science Education, 14, 1-11.

Wicaksono, I., Wasis, \& Madlazim. (2017). The effectiveness of virtual science teaching model (VS-TM) to improve student's scientific creativity and concept mastery on senior high school physics subject. Journal of Baltic Science Education, 16(4), 549561 .

Yunus, S. R., Sanjaya, I. G. M., \& Jatmiko, B. (2013). Implementasi pembelajaran fisika berbasis guided inquiry untuk meningkatkan hasil belajar siswa auditorik. Jurnal Pendidikan IPA Indonesia, 2(1), 48-52.

Zakar, Z., \& Baykara, H. (2014). Inquiry-based laboratory practices in a science teacher training program. Eurasia Journal Mathematics, Science and Teaching Education, 10(2), 173-183.

Zulkarnaen, Supardi, Z. A. I, \& Jatmiko, B. (2017). Feasibility of creative exploration, creative elaboration, creative modeling, practice scientific creativity, discussion, reflection (C3PDR) teaching model to improve students' scientific creativity of junior high school. Journal of Baltic Science Education, 16(6), 1020-1034. 